IRA-International Journal of Applied Sciences ISSN 2455-4499; Vol.04, Issue 01 (2016)

\title{
Productivity of Rainfed Castor as Influenced by Plant Geometry and Nitrogen Levels
}

\author{
${ }^{1}$ E. Aruna \& ${ }^{2}$ G. Karuna Sagar \\ 1,2 Agricultural Research Station, \\ Utukur, Kadapa, India.
}

DOI: http://dx.doi.org/10.21013/jas.v4.n1.p1

\section{How to cite this paper:}

Aruna, E., \& Sagar, G. (2016). Productivity of Rainfed Castor as Influenced by Plant Geometry and Nitrogen Levels. IRA-International Journal of Applied Sciences (ISSN 2455-4499), 4(1). doi:http://dx.doi.org/10.21013/jas.v4.n1.p1

(C) Institute of Research Advances

\section{(cc)) Br-No}

This works is licensed under a Creative Commons Attribution-Non Commercial 4.0 International License subject to proper citation to the publication source of the work.

Disclaimer: The scholarly papers as reviewed and published by the Institute of Research Advances (IRA) are the views and opinions of their respective authors and are not the views or opinions of the IRA. The IRA disclaims of any harm or loss caused due to the published content to any party. 


\section{ABSTRACT}

Field experiment was conducted at Agricultural Research Station, Utukur,Kadapa of Acharya $N$ G Ranga Agricultural University to study the performance of rainfed castor hybrid PCH 111 under varied levels of nitrogen with different planting patterns during kharif seasons of 2012 and 2013.The study was laid out in a split plot design with three replications comprising of three planting patterns, viz., $90 \mathrm{~cm} \times 30 \mathrm{~cm}\left(P_{1}\right), 90 \mathrm{~cm} \times 45 \mathrm{~cm}\left(P_{2}\right), 90 \mathrm{~cm} \times 60 \mathrm{~cm}\left(P_{3}\right)$ and three nitrogen levels viz., $60 \mathrm{~kg} \mathrm{ha}$ $\left(N_{1}\right), 90 \mathrm{~kg} \mathrm{ha}^{-1}\left(N_{2}\right)$, and $120 \mathrm{~kg} \mathrm{ha} \mathrm{g}^{-1}\left(N_{3}\right)$. Number of spikes per plant and number of capsules per spike (58.84, 69.07 in 2012 and 2013 respectively) were more when castor was planted at $90 \mathrm{~cm} \times 45 \mathrm{~cm}$. Hundred seed weight and seed yield were not significantly influenced by planting geometry. Application of $120 \mathrm{~kg} \mathrm{~N} \mathrm{ha}^{-1}$ recorded higher number of spikes per plant and capsules per spike but it was on par with $90 \mathrm{~kg} \mathrm{~N} \mathrm{ha} a^{-1}$. Seed yield was higher with application of $120 \mathrm{~kg} \mathrm{~N} \mathrm{ha} \mathrm{k}^{-1}$ in both the years but it was on par

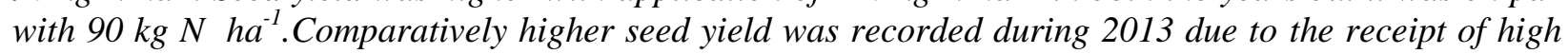
rainfall.

Key words: Rainfed castor, Plant geometry, Nitrogen levels, Yield attributes and Seed yield

\section{INTRODUCTION}

India is the largest producer of castor and contributes to around 65 per cent of world production dominating the global trade with a share of more than eight per cent. Gujarat ranks first with regards to area $(57 \%)$, production $(82.9 \%)$, and productivity $\left(2010 \mathrm{~kg} \mathrm{ha}^{-1}\right)$. The productivity of castor in Andhra Pradesh is very low, because castor is grown on marginal and sub marginal soils under rainfed conditions, coupled with incidence of a host of biotic stresses like pests and diseases such as Heliothis and Botrytis, besides low input use and poor level of crop management by the resource poor farmers. As a consequence, cultivation of castor during kharif, under rainfed conditions has become less remunerative. Enhanced production is possible mainly through appropriate agro techniques such as genotypes sown at optimum time, maintaining optimum plant stand and judicious use of nutrients. Crop geometry is an important factor to achieve higher production by better utilization of moisture and nutrients from the soil by harvesting the maximum possible solar radiation and in turn better photosynthate formation (Thavaprakaash et al., 2005). There is no systematic information available on plant geometry and nitrogen requirement of hybrid castor (PCH- 111) grown under rainfed conditions in Alfisols of Kadapa region. Therefore, the present study was taken up to find out optimum plant population and nitrogen requirement for hybrid castor in alfisols.

\section{MATERIAL AND METHODS}

A field experiment was conducted during the kharif seasons of 2012 and 2013 at Agricultural Research Station, Utukur, Kadapa on Alfisols. The experimental soil was low in available nitrogen (139 $\left.\mathrm{kg} \mathrm{ha}^{-1}\right)$, high in available phosphorus $\left(87 \mathrm{~kg} \mathrm{ha}^{-1}\right)$ and potassium $\left(460 \mathrm{~kg} \mathrm{ha}^{-1}\right)$ with $\mathrm{P}^{\mathrm{H}} 8.27$ and EC 0.06 $\mathrm{dS} \mathrm{m}{ }^{-1}$. The experiment was laid out in split plot design with three replications. The treatments consisted of three plant geometries viz., $90 \mathrm{~cm}$ x $30 \mathrm{~cm}, 90 \mathrm{~cm}$ x $45 \mathrm{~cm}$ and $90 \mathrm{~cm} \mathrm{x} 60 \mathrm{~cm}$ as main plot treatments and three nitrogen levels viz., 60, 90 and $120 \mathrm{~kg} \mathrm{ha}^{-1}$ sub plot treatments. Half of nitrogen dose and full dose of phosphorus $\left(40 \mathrm{~kg} \mathrm{ha}^{-1}\right)$ and potassium $\left(30 \mathrm{~kg} \mathrm{ha}^{-1}\right)$ were applied as basal and the remaining half of nitrogen was top dressed in two splits at 30 and 60 DAS. The test variety PCH -111 was sown on 14th July and $10^{\text {th }}$ July during 2012 and 2013 respectively with the onset of monsoon. All cultural management practices (thinning, interculturing and weeding) were followed whenever needed. Necessary plant protection measures were taken up as and when required. The crop was harvested periodically as per maturity of spike. After complete harvesting, threshing was done and yield was recorded net plot wise and converted on hectare basis. A total of $472 \mathrm{~mm}$ rainfall in 38 rainy days during 2012 and $919 \mathrm{~mm}$ rain fall in 44 rainy days was received during 2013. 


\section{RESULTS AND DISCUSSION}

\section{Effect of planting geometry}

Taller plants were observed when castor was sown with closer spacing of $90 \mathrm{~cm}$ x $30 \mathrm{~cm}(152$ $\mathrm{cm}$ and $357 \mathrm{~cm}$ in 2012 and 2013) in both the years. However during the second year, it was on par with $90 \mathrm{~cm} \times 45 \mathrm{~cm}(348 \mathrm{~cm})$. The receipt of heavy rainfall of $919 \mathrm{~mm}$ during 2013 resulted in robust growth of castor in the second year. In contrast, Soratto et al. (2012) reported taller plants with wider plant geometry. The probable reason for such positive response due to wider geometry might be sufficient rooting and moisture extraction pattern which helped better absorption of water and nutrients. Planting geometry did not significantly influence the number of branches in 2012-13. But, planting at $90 \mathrm{~cm} \times 60$ $\mathrm{cm}$ recorded more number of branches (5.11) which was on par with $90 \mathrm{~cm} \mathrm{x} 45 \mathrm{~cm}$ (4.35). Closer planted castor $(90 \mathrm{~cm} \times 30 \mathrm{~cm})$ recorded lower number of branches in both the years. It might be due to competition for sunlight, water, nutrients, and space. These results are in conformity with Porwal et al. (2005) and Bhunia et al. (2012) in castor. Number of spikes per plant was more with $90 \mathrm{~cm} \mathrm{x} 45 \mathrm{~cm}$ (3.42) in 2012-13 whereas more number of spikes per plant was recorded with $90 \mathrm{~cm} \mathrm{x} 60 \mathrm{~cm}(5.24)$ in 2013-14 but it was on par with $90 \mathrm{~cm} \times 45 \mathrm{~cm}$ (4.93). This might be due to more radiation interception above the canopy and higher availability of nutrients and water below canopy to the individual plant under wider crop canopy during the growth cycle of the crop. The variability of micro climate condition of a crop alters the number of spikes plant ${ }^{-1}$ and variability in the yield. This is in agreement with the earlier findings of Kittock and Williams (1970) in castor. Reduced number of spikes under closer spacing might be due to higher competition for nutrients, space and air between the plants. Spike length was not significantly influenced by planting geometry in both the years. The number of capsules per spike was not influenced significantly by spacings in 2012-13. But, higher number of capsules per spike (69.07) was recorded by $90 \mathrm{~cm}$ x $45 \mathrm{~cm}$ which was on par with $90 \mathrm{~cm}$ x $60 \mathrm{~cm}$ (63.24) in 2013-14. Hundred seed weight was not significantly influenced by planting geometry in both the years. Seed yield was not significantly influenced by planting geometry in both the years. The seed yield was comparatively higher by $45-50 \%$ in 2013-14 due to receipt of high rain fall of $919 \mathrm{~mm}$ in 44 rainy days.

\section{Effect of nitrogen}

Application of $120 \mathrm{~kg} \mathrm{~N}^{-1}$ recorded taller plants in the first year whereas nitrogen did not significantly influence the plant height in the second year. This improvement in crop growth might be because of the increased availability and uptake of nitrogen at higher N levels. Yadav et al. (2002) also reported similar observations. Number of branches was not significantly influenced by nitrogen in both the years. Number of spikes per plant was more with $120 \mathrm{~kg} \mathrm{~N}$

$\mathrm{ha}^{-1}$ in 2012-13 but it was not influenced significantly by nitrogen in 2013-14. Spike length was more with application of $120 \mathrm{~kg} \mathrm{~N} \mathrm{ha}^{-1}(50.3 \mathrm{~cm})$ which was on par with $90 \mathrm{~kg} \mathrm{~N}(50 \mathrm{~cm})$ during 2012-13 whereas it was insignificant in 2013-14. Higher number of capsules per spike were recorded with $120 \mathrm{~kg}$ $\mathrm{N} \mathrm{ha}^{-1}$ but was on par with $90 \mathrm{~kg} \mathrm{~N} \mathrm{ha}^{-1}$ in 2013-14. Whereas the capsule number per spike was insignificant in 2012-13. Hundred seed weight was not significantly influenced by nitrogen in both the years. Significantly higher seed yield was recorded with $120 \mathrm{~kg} \mathrm{~N} \mathrm{ha}^{-1}$ in both the years but it was on par with $90 \mathrm{~kg} \mathrm{~N} \mathrm{ha}^{-1}$. The favourable effect of high doses of nitrogen on yield attributes and their cumulative effect on seed yield were mainly responsible for higher seed yield

It was concluded that planting at $90 \mathrm{~cm} \times 45 \mathrm{~cm}$ and application of $90 \mathrm{~kg} \mathrm{~N}^{-1}$ was found optimum for hybrid castor in alfisols of kadapa region under rainfed conditions. 


\section{REFERENCES}

Bhunia, S.R., R.P.S. Chauhan and B.S. Yadav. 2012. Effect of plant geometry and irrigation levels on productivity, yield components, water use and water use efficiency of castor (Ricinus communis) in canal command areas of north-western Rajasthan. J. Rural Agric. Res., 12(2): 37-39.

Kittock, D.L. and J.H. Williams. 1970. Effect of plant population on castor bean yield. Agron. J., 62: 527 529.

Porwal, M.K., S.K. Agarwal and A.K. Khokar. 2005. Effect of planting methods and intercrops on productivity and economics of castor (Ricinus communis) based intercropping systems. Indian J. Agron., 51(4): 274-277.

Soratto, P., G.D. Souza Schlick, A.M. Fernandes, M.D. Zanotto and C.A.C. Crusciol. 2012. Narrow row spacing and high plant population to short height castor genotypes in two cropping seasons. Industrial Crop Prod., 35: 244-249.

Thavaprakaash, N., K. Velayudham and V.B. Muthukumar. 2005. Effect of crop geometry, intercropping systems and integrated nutrient management practices on productivity of baby corn (Zea mays L.) based inter cropping system. Res. J. Agri. Bio. Sci., 1(4): 295-302.

Yadav,K.,Prasad,V.,Ahmed,N and Mandal,K.2002. Response of maize (Zea mays) genotypes to azospirillum lipoferum in calcareous soils. Journal of Indian society of Soil Sciences 40(1): 19597. 
Growth and yield of rainfed castor as influenced by plant geometry and nitogen

\begin{tabular}{|c|c|c|c|c|c|c|c|c|c|c|c|c|c|c|}
\hline \multirow[t]{2}{*}{ Treatment } & \multicolumn{2}{|c|}{$\begin{array}{c}\text { Plant } \\
\text { height }(\mathrm{cm})\end{array}$} & \multicolumn{2}{|c|}{$\begin{array}{c}\text { No. of } \\
\text { branches }\end{array}$} & \multicolumn{2}{|c|}{$\begin{array}{c}\text { No.of spikes } \\
\text { /plant }\end{array}$} & \multicolumn{2}{|c|}{ Spike length(cm) } & \multicolumn{2}{|c|}{$\begin{array}{c}\text { No.of } \\
\text { capsules/spike }\end{array}$} & \multicolumn{2}{|c|}{$\begin{array}{c}100 \text { seed } \\
\text { weight }(\mathrm{g})\end{array}$} & \multicolumn{2}{|c|}{$\begin{array}{c}\text { Seed yield } \\
\left(\text { kgha }^{-1}\right)\end{array}$} \\
\hline & 2012 & 2013 & 2012 & 2013 & 2012 & 2013 & 2012 & 2013 & 2012 & 2013 & 2012 & 2013 & 2012 & 2013 \\
\hline \multicolumn{15}{|l|}{ Spacing $(\mathbf{c m})$} \\
\hline $90 \mathrm{~cm} \times 30 \mathrm{~cm}$ & 152 & 357 & 3.00 & 4.11 & 3.17 & 4.42 & 46.6 & 60.02 & 57.76 & 61.40 & 24.83 & 24.66 & 991 & 2215 \\
\hline $90 \mathrm{~cm} \times 45 \mathrm{~cm}$ & 142 & 348 & 3.88 & 4.35 & 3.42 & 4.93 & 49.5 & 58.27 & 58.8 & 69.07 & 25.01 & 24.88 & 1043 & 2202 \\
\hline $90 \mathrm{~cm} \times 60 \mathrm{~cm}$ & 132 & 331 & 3.37 & 5.11 & 2.75 & 5.24 & 48.8 & 59 & 55.36 & 63.24 & 24.43 & 24.66 & 921 & 2151 \\
\hline SEm + & 1.7 & 5.20 & 0.23 & 0.29 & 0.11 & 0.22 & 1.7 & 2.39 & 4.55 & 1.92 & 0.81 & 0.77 & 62 & 77 \\
\hline CD (0.05) & 6.69 & 20.44 & $\mathrm{NS}$ & 0.89 & 0.46 & 0.67 & NS & NS & NS & 7.54 & NS & NS & NS & NS \\
\hline \multicolumn{15}{|c|}{ Nitrogen levels $\left(\mathrm{kg} \mathrm{ha}^{-1}\right)$} \\
\hline 60 & 139 & 309 & 3.11 & 4.44 & 2.43 & 5.17 & 46.8 & 59.42 & 57.13 & 65.96 & 25.29 & 24.77 & 850 & 2105 \\
\hline 90 & 102 & 354 & 2.84 & 4.53 & 2.90 & 4.50 & 50.0 & 58.31 & 55.62 & 67.71 & 25.45 & 25.88 & 1002 & 2250 \\
\hline 120 & 147 & 346 & 3.31 & 4.60 & 3.40 & 5.06 & 50.3 & 60.42 & 59.20 & 72.04 & 25.78 & 23.55 & 1118 & 2481 \\
\hline SEm+ & 2.42 & 14.09 & 0.20 & 0.29 & 0.13 & 0.22 & 0.96 & 2.39 & 4.55 & 1.87 & 0.82 & 0.77 & 38 & 77 \\
\hline CD (0.05) & 7.45 & NS & NS & NS & 0.41 & NS & 2.97 & NS & NS & 5.77 & NS & NS & 117 & 231 \\
\hline
\end{tabular}

